\title{
Differences in Knowledge Science in Islamic Education Philosophy Perspective
}

\author{
Sukman Sappe \\ Islamic State College of Sorong (STAIN Sorong), Indonesia \\ *e-mail: sukmansorong@gmail.com
}

\section{Article Information}

Received: March 20, 2020

Revised: May 12, 2020

Online: June 26, 2020

$\frac{\text { Keywords }}{\text { dichotomy, Islamic education, }}$

philosophy perspective

\begin{abstract}
The dichotomy of science is the separation between general science and religion, which then develops into other dichotomic phenomena. The term science dichotomy in various historical literature, including the afterlife and world sciences, syar'iyah science and ghairu syar'iyyah Science, al'ulum al-diniyyah and al-'ulum al-'aqliyyah, Islamic Knowledge and Non-Islamic Knowledge (English), Hellenic and Semitic (Greek). The consequences of the dichotomy, as mentioned as the terms of the dichotomy, have implications for the alienation of the religious sciences to modernity and keep the progress of science away from spiritual values. In the perspective of Islamic education, science is an in-depth knowledge of the results of earnest efforts (ijtihād) from Muslim scientists ('ulamā'/mujtahìd) on practical and ukhrāwì issues by originating from the revelations of Allah Almighty so that science grows and develops hand in hand with religion. In the history of Islamic civilization, scholars live in harmony with scientists, many scientists found in Islam, as well as scholars
\end{abstract}

\section{INTRODUCTION}

Normatively, Islam appreciates the mastery of knowledge so that it is seen as a whole and universal, there is no term separation or dichotomy. The Qur'an also emphasizes that Muslims seek knowledge by examining the universe, and for those who seek knowledge are elevated in the sight of Allah, not even those who know and those who do not know. This is the word of Allah in QS. al-Mujadalah / 58: 11:

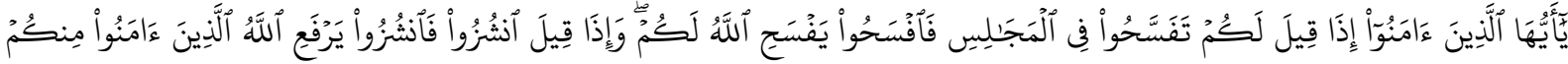

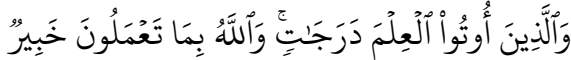

0 you who have believed, when you are told, "Space yourselves" in assemblies, then make space; Allah will make space for you. And when you are told, "Arise," then arise; Allah will raise those who have believed among you and those who were given knowledge, by degrees. And Allah is Acquainted with what you do.

Science and religion are integral totality that cannot be separated from one another. Indeed, Allah is the one who created the reason for humans to study and analyze what is in nature as a lesson and guidance for humans in carrying out their lives in the world. Historically, before the destruction of the Mu'tazilah theology at the time of the Caliph al-Ma'un (198-218 H / 813-833 AD), studying general sciences (empirical reasoning studies) existed in the madrasa curriculum. The acceptance and 
prohibition of the use of reason after the fall of Mu'tazilah, the general sciences suspected of being eliminated from the madrasa curriculum. Those who are interested in studying general sciences and who have a scientific enthusiasm to prove the truth of the verses of kauniyah forced to consider individually or underground because they have seen as subversive sciences that can challenge the establishment of Sunni doctrine, especially in kalam and fiqh. The existence of Madrasa at Tibb (Medical School) also cannot develop medical science freely because it is often sued by jurists, for example, not allowed to use corpse organs even if they are dissecting to be investigating. Likewise, research hospitals in Baghdad and Cairo, because they are overshadowed by rigid fiqh legalism so that they concentrate on academic medicine and care.

Based on the above, it shows that in historical reality, there has been a disharmony of relations between the religious sciences and general (secular) sciences, which has led to a dichotomy between religious education and public education. The birth of educational dualism resulted in the decline of Muslims in various fields, along with the progress of the West (Europe), which mastered various sciences and tried to uncover the mysteries of nature and conquer the seas and the land.

Fanaticism in religion is also one of the factors that led to the emergence of the dichotomy of science. The attitude of intolerance in worship in social life gave birth to a philosophy of exclusivism. Islamic movements, including in the exclusive movement category. Private in the sense of the emergence of the thought that truth and salvation only exist in religion, other people's faith is all wrong. Other people's beliefs are entirely different and don't have the slightest salvation, so there is no need for dialogue because it will not reach a meeting point. They only associate with their groups and isolate themselves from others, refuse to cooperate in solving problems, and sometimes like to use violence in resolving differences outside their religion.

The above reality reminds us that the attitude of isolating oneself from the system of thought or social life also influences the pattern or scientific method in Islam itself. Yet as we know that the tendency to shut down makes a scientific discipline. In this case, the Islamic experimental system becomes incomplete again, formed partially and scattered, which in turn creates the instability between physical and spiritual.

The dichotomy of science is a historical process that entrenched in the life of the Islamic Ummah. The dichotomy was born from the context of time-space and intertwining the lives of Muslims in a certain period, which is influenced by various factors, including ideological, political, social, and cultural factors.

In its development, the apparent dichotomy has implications for thinking models. On the one hand, there is an education that only deepens modern science, which is devoid of religious values. On the other hand, there is an education that only increases the issue of religion that is separate from the development of science.

\section{METHODS}

The research method used in this study is library research done by collecting articles or scientific papers related to learning planning, learning design, learning model. This research is qualitative, by observing phenomena in Indonesia, formulating problems that occur, and then related to the obtained literature. Data collection techniques are performed by tri-formulating (combined) literature review by collecting data, exceptionally verbal data, through books, articles, notes, and various other scientific literature. The data collected are then analyzed inductively to produce grounded theory, a theory that emerges from non-hypothesis data (Setyosari, 2013). Writing steps to prepare this article: 1) Choosing a problem; 2) a preliminary study; 3) formulating a problem; formulating objectives; 4) conducting a study; 5) making a discussion; 6) formulating conclusions drawn from analysis results and recommendations for other authors.

\section{RESULTS}

The term dichotomy of knowledge is merely differentiating or classifying science into religious knowledge and non-religious knowledge, in fact it is not a problem as long as it is not excessive, let alone discriminating against one of the two. Actually, the dichotomy of science into religious and non-religious sciences is not new. Islam has had this dichotomy tradition more than a thousand years ago. But this dichotomy did not cause too many problems in the Islamic education system, until the Western secular

IJAE Page 2 
education system was introduced to the Islamic world through imperialism. The problem is when the dichotomy paradigm of science becomes part of the Muslim perspective which eliminates one of the sciences by classifying high education and low education or the superiority of science and inferior science.

In classification, they do distinguish the two, but in principle they are positioned in the same status and position, so that they both get the same portion to be explored, causing a symbiotic-mutualism interaction between the two domains of knowledge. This means that between one another is not an antithesis of the other, but simultaneously becomes a "dual-singular" which contributes to each other.

The views and attitudes of scientists at the time of the Prophet Muhammad SAW, who positioned knowledge in parallel, led to exploration of knowledge other than religious knowledge, although in a very simple level. Even the prophet Muhammad never taught his faithful and pious followers to stay away from the world which is a medium in reaching the perfection of life. These values were seen when Islam was born in the first half of the 7th century AD, the Arabs were surrounded by nations that had high and magnificent cultures, such as Persia, Rome, Greece, and India. There is already a kind of knowledge which later has influenced the development of Islamic religious knowledge.

Etymologically, the term dichotomy comes from the English dichotomy, which means the division of two parts, bisection, two branches. Whereas in the Big Indonesian Dictionary, the dichotomy is defined as the division in two conflicting groups. Thus, the word dichotomy is using to distinguish or separate two different things.

In terms of terminology, the dichotomy is the separation between science (general) and religion, which then develops into other dichotomic phenomena. A dichotomy is a careful and clear separation of types into two separate from one another where one cannot include in the other and vice versa. So dichotomy is a term used to separate the character of religion and general science as if used separately. Such matter cannot be separating from the historical-cultural background, which in the process of development, there is a boundary between the two domains.

The term dichotomy of science in a variety of different historical literature, and to distinguish the religious sciences from the general sciences many different discourse terms are used, including the words of the afterlife and world sciences, some are calling it syar ' iyyah and science of ghairu syar'iyyah, there are even other names like al-'ulum al-diniyyah and al-'ulum al-'aqliyyah. So basically the term education dichotomy is focused on only two major parts, namely the tanziliyah sciences, namely the sciences developed by human reason related to the values revealed by Allah, both in the book and the hadiths of the Prophet Muhammad, and the sciences - kauniyyah Science, the sciences developed by human reason because of their interaction with nature. In English terms, the difference in words used is known as Islamic Knowledge and Non-Islamic Knowledge. The term dichotomy turns out to have a considerable influence, not only for Islamic education but also for non-Islamic religions, namely other major religions, namely Christianity and Judaism.

Another term for the dichotomy of science that is more dipping in the roots of science is the view of A. Malik Fadjar, who termed the dichotomy with Hellenic for general or modern Science and Semitic for religion. Hellenistic ideas come from classical Greek whose prominent features give a considerable portion to the authority of reason, give priority to rational attitudes and favor secular sciences. Thus, in Greek times the dichotomy of knowledge widened far beyond what it is today.

Another term that was revealed by Harun Nasution in the book Rational Islam that he called the attitude that separates science with the term dualism of science. In polarity, the essential elements of each reality tend to be opposed but do not deny each other; for example, in theology as Harun Nasution's scientific fields exemplify evil and goodness, God and the universe, spirit and body, soul and body, etc.

of the many terms used in the dichotomy of Islamic education, in general, all names used are conical to the difference between religious and general science, which means that all the existence of science is opposed and separated from one another in a frame of reality that is segmented into subsystems that are each - stand-alone. The consequences of the dichotomy, as mentioned above, will have implications for the alienation of the religious sciences to modernity and keep scientific progress away from spiritual values. If the term dichotomy of science is merely to distinguish it from the purpose of classifying science into religious and non-religious sciences, then the dichotomy becomes ordinary (can be of positive value). But if the dichotomy of science is to discriminate against one of the sciences, then this will harm each of the sciences. 
In the historical process, the dichotomy begins with the development of Islamic-Arabic meetings with other cultures and then continues with the development of educational institutions in Islam and ends with the clash of two ways of thinking that are quite influential in the formation of the dichotomy of science in the history of Islamic civilization. Islam, which has initially been universal, accommodated all problems and aspects of life, found a point of division when there was a meeting with philosophical sciences which incidentally originated from non-Islam.

In the context of Islamic education, the dichotomy is better understood as the dualism of the education system between Islamic religious education and general education that separates spiritual awareness and science. The dichotomous education system in Islamic education will cause the breakup of Islamic civilization and will deny the kaffah and universal Islamic culture.

In general, analyzing and evaluating the logical implications of something on something else is by looking at the conditions before and after something happened. [7] Religious education through madrasas, religious institutes and pesantren is managed by the Ministry of Religion, while general education through primary, secondary and vocational schools and general universities is managed by the Ministry of National Education. Islamic education does not merely teach Islamic knowledge theoretically so that it only produces an Islamologist, but Islamic education also emphasizes the formation of Islamic attitudes and behavior in other words forming an Islamist human being. The following are the implications of the education dichotomy:

\section{The Ambivalence of the Orientation of Islamic Education}

One of the negative impacts of the dichotomy of the education system, especially in Indonesia, is the emergence of an ambivalence in the orientation of Islamic education. [8] Here we can observe, in pesantren education there are still deficiencies in the educational program. For example, education in the muamalah field includes mastery of various disciplines and skills. There is an assumption that all of these are not areas of Islamic work, but secular education. When educational orientation experiences a dichotomy, it will have an impact on the curriculum or material presented. In a material there will be a separation between religious knowledge and non-religious knowledge. So that one of the two will be sidelined and there will be priority.

2. The gap between the Islamic Education System and Islamic Teachings.

The education system which is still ambivalent reflects the dichotomous view that separates the religious sciences from the general sciences. This view contradicts the teachings of Islam itself. Islam has an integralistic teaching which teaches that world affairs are inseparable from matters of the hereafter, but constitute a unity. Therefore, general sciences must be understood as an integral part of the religious sciences. Islam does not prohibit us from studying general sciences. For the needs of our life in this world, we also have to study, know, then apply it in our daily life, to help us live in a world that will lead to life in the hereafter.

3. Disintegration of the Islamic Education System

With the existence of the education dichotomy, this will have an impact on the disintegration of the education system, namely the incompatibility and uncertainty of the relationship between general education and religious education. In looking at the two sciences there is no equation in assessing, it is more likely that there will be one of the main goals of an educational institution in carrying out the learning process. So that the two sciences cannot go hand in hand and become a unified whole.

\section{DISCUSSION}

The word science comes from the Arabic' ilm ('Alima-ya Lamu-'ilm), which means knowledge (alma'rifah), then develops into knowledge about the nature of something deeply understood. From the origin of the word 'ilm, it is then Indonesianized to be' science 'or' science. 'In an Islamic perspective, Science is an in-depth knowledge of the results of earnest effort (ijtihād) from Muslim scientists (' ulamā' / mujtahīd) on practical and ukhrāwī issues with their source from the revelation of God.

Al-Qur'an and al-Hadits are revelations of God that function as guidance (hudan) for humanity, including in this case are instructions about science and scientific activity. The Qur'an gives extraordinary attention to scientific activities. The verse that first came down reads, "Read, by [mentioning] the name of your Lord who created." Reading, in its broadest sense, is a significant activity in scientific activities. Also, the word science that has become Indonesian does not only come from Arabic but is also listed in the Qur'an. The word science is mentioned 105 times in the Qur'an. While the 
name invented is called as much as 744 times. The term coined is meant; 'Alima ( 35 times), ya'lamu (215 times), i'lām (31 times), yu'lamu (1 time),' alīm (18 times), ma'lūm (13 times), 'ālamīn (73 times), 'nature (3 times),' a'lam (49 times), 'alīm or' ulamā '(163 times),' allām (4 times), 'Allama (12 times), yu'limu (16 times) ), 'ulima (3 times), mu'allām (1 time), and ta'allama (2 times).

In addition to the word science, in the Qur'an, there are also many verses that, directly or indirectly, refer to scientific activities and the development of science, such as commands to think, reflect, reason, and the like. For example, the words' aql (idea) in the Qur'an is mentioned 49 times, once in the past verb form, and 48 times in the present verb form. One of them is: "Truly the worst creeping things in the sight of Allah are those who are deaf and mute, who do not use their minds." The word fikr (mind) is mentioned 18 times in the Qur'an, once in the past verb form and 17 times in the present verb form. One of which is; "... those who always remember Allah when standing, sitting or lying, and thinking about the events of heaven and earth". Regarding the position of the scientist, the Qur'an states: "Allah will raise the degrees of believers and some degree of knowledge."

In addition to al-Qur'an, in the Prophet's Hadits, there is much mention of scientific activities, the priority of the prosecutors of science/scientists, and ethics in seeking knowledge. For example, the hadiths that read; "Studying knowledge is an obligation for every Muslim and Muslim" (HR. BukhariMuslim). "Whoever goes out of the house in order to study, angels will protect with both wings" (HR. Turmudzi). "Whoever leaves the house in order to study, he is always in the way of Allah until he returns" (HR. Muslim). "Whoever studies to keep a distance from fools, or for the purpose of respected by humans, Allah will put that person into hell" (HR. Turmudzi).

The great attention of Islam to Science, attracts the attention of Franz Rosenthal, an Orientalist, by saying: "Actually there is not a single concept that operatively plays a decisive role in the formation of Islamic civilization in all its aspects, which has the same impact as the concept of science. This is still true, even among the most important terms in the religious life of Muslims, such as "tauhîd" (recognition of the oneness of God), "al-dîn" (true religion), and many more words which are continuously and passionately mentioned. None of these terms has a depth in meaning that is broad in their use, which is the same as the word science. There is not a single branch in the intellectual life of Muslims who is not touched by such a pervasive attitude towards "knowledge" as having the highest value in becoming a Muslim. "

The explanations of al-Qur'an and al-Hadits above show that the paradigm of Science in Islam is theocentric. Therefore, the relationship between science and religion shows a harmonious relationship; Science grows and develops in harmony with faith. Thus, in the history of Islamic civilization, scholars live in peace alongside scientists. In fact, many scientists are found in Islam as well as scholars. For example, Ibn Rusyd, aside from being an Islamic jurist author of the book Bidāyah al-Mujtahīd, is also a medical expert composing the paper al-Kullīyāt fì al-Thibb. In general, knowledge in Islam can be classified into three groups, which include; metaphysics occupies the highest position, followed later by mathematics, and finally, the physical sciences. Through these three science groups, various scientific disciplines were born, for example; in the metaphysical sciences (ontology, theology, cosmology, angelology, and eschatology), in the mathematical sciences (geometry, algebra, arithmetic, music, and trigonometry), and in the physical sciences (physics, chemistry, geology, geography, astronomy, and optics). In subsequent developments, along with the times, the progress, and for practical purposes, a number of scholars try to classify science. Al-Ghazali divided knowledge into two parts; fardhu' ain and fardhu kifāyah. The science of fardhu 'ain is the science that must be learned by every Muslim in relation to the conduct of compulsory acts, such as the knowledge of prayer, fasting, purification, and the like whereas the science of fardhu kifāyah is the science that must be mastered for the sake of upholding world affairs, such as; medical science, astronomy, agriculture, and the like. In fardhu kifāyah Science, not every Muslim is required to master it. The important thing is that each region represents something, then the obligations for others fall.

In addition to the above division, al-Ghazali still divides knowledge into two groups, namely, syarī'ah Science and ghair syari’'ah science. All shariah science is commendable and is divided into four kinds; principal (ushūl), branch (furū'), introduction (muqaddimāt), and supplement (mutammimāt). The science of ushul includes; al-Qur' ān, Sunnah, Ijmā 'Ulamā', and Atsār Shahābāt. Furū 'includes; The Science of Fiqh relating to the benefit of the world, and the knowledge of matters and temperaments, both praiseworthy and despicable. The philosophy of muqaddimāt is intended as an indispensable tool

IJAE Page 5 
for learning ushul culture, such as Arabic (Nahw, Sharf, Balāghah). Mutammimāt is the sciences that relate to the Science of the Qur'an such as; The Science of Makhārij al-Hurūf wa al-Alfādz and the Science of Qirā'at. While the science of ghair syarī'ah by al-Ghazālī is divided into three; commendable sciences (al--ulūm al-mahmūdah), permissible sciences (al--ulūm al-mubāhah), and despicable sciences (alūulūm al-madzmūmah). Praised science is the sciences needed in the lives of humanity, such as medicine, agriculture, technology. Allowed knowledge is knowledge about culture such as; history, literature, and poetry that can awaken the virtues of noble morals while the reprehensible experience is the sciences that can endanger the owner or others such as; witchcraft, astrology, and several branches of philosophy.

Ibn Khaldun divided knowledge into two groups, namely, naqliyah sciences that originate from sharia' and 'aqliyah sciences/philosophies originating from thought. Included in the naqliyah sciences group are; Interpretation, Qirā'ah, Hadīts, Ushūl Fiqh, Fiqh, Kalam Science, Arabic (Linguistics, Grammar, Rhetoric, and Literature) while those included in the sciences' aqlīyah are; Mantiq Sciences, Natural Sciences, Metaphysics, and Instructive Sciences (Measurement Science, Calculating Science, Music Science, and Astronomy). Second, the science of logic that includes understanding, benefits, syllogism, and the like. Third, prophetic science, which includes arithmetic, geometry, optics, astronomy, astrology, music, and others. Fourth, physics and mathematics. Fifth, social Science, legal Science, and kalam science.

Ibn Buthlān (died 1068 AD) made the classification of science into three major branches; Islamic (religious) sciences, philosophical and natural sciences, and literary sciences. The relation of these three branches of science is described as a triangle; the right side is the religious sciences; the left side is the philosophy and natural sciences, while the lower side is literature.

The World Conference on Islamic Education II in Islamabad Pakistan in 1980 recommended the grouping of knowledge into two kinds, namely, perennial/everlasting knowledge (naqlīyah) and acquired knowledge/acquisition ('aqlīyah). Included in perennial science groups are; al-Qur'ān (including; Qirā'ah, Hifdz, Tafsir, Sunnah, Sīrah, Tawheed, Ushūl Fiqh, Fiqh, Arabic al-Qur'ān consisting of Phonology, Syntax, and Semantics), and Auxiliary Sciences (Ushūl Fiqh, Fiqh, Arabic al-Qur'ān consisting of Phonology, Syntax, and Semantics), and Auxiliary Sciences (Ushul include: Islamic Metaphysics, Comparative Religion, and Islamic Culture). While those involved in the acquired science are; Arts (including; Islamic Arts and Architecture, Language, Literature), Intellectual Sciences / theoretical social studies, (including; Philosophy, Education, Economics, Political Science, History, Islamic Civilization, Geography, Sociology, Linguistics, Psychology, and Anthropology ), Natural / theoretical Sciences (including; Philosophy of Science, Mathematics, Statistics, Physics, Chemistry, Life Sciences, Astronomy, Space Sciences, etc.), Applied Sciences (including; Engineering and Technology, Medicine, and so on), and Practical Sciences (including; Commerce, Administrative Sciences, Library Sciences, Housekeeping Sciences, Communication Sciences).

Nurcholish Madjid, Muslim scholars from Indonesia, grouped Islamic sciences into four parts, namely; Fiqh, Sufism, Kalam Science, and Philosophy. The Science of Fiqh deals with the formal aspects of worship and law, the Science of Sufism deals with aspects of religious observance and practice that are more personal, Kalam Science deals with issues of God and its various derivatives, whereas Philosophy deals with matters that are speculative contemplative about life in the broadest sense. Included in the scope of Philosophy are "general sciences," such as; metaphysics, medicine, mathematics, astronomy, art.

The classification of Islamic sciences by Muslim scientists above confirms that the scope of Science in Islam is comprehensive, covering worldly and ukhrāwi affairs. The limits of knowledge in Islam are; that the development of expertise must be within the framework of monotheism within the context of devotion to God and for the welfare of humanity. Thus, science is not just science, but the knowledge to be practised. And the experience is not a goal, but merely a means to serve God and the benefit of the people.

\section{CONCLUSION}

Based on the discussion above, the conclusions in this paper are as follows:

1. The dichotomy of science is the separation between general science and religion, which then develops into other dichotomic phenomena. The term science dichotomy in various historical

IJAE Page 6 
literature, including the afterlife and world sciences, syar'iyyah science and ghairu syar'iyyah Science, al-'ulum al-diniyyah and al-'ulum al-'aqliyyah, Islamic Knowledge and Non-Islamic Knowledge (English), Hellenic and Semitic (Greek). So the term dichotomy of science is divided into two parts, namely the tanziliyah sciences, namely the sciences developed by human reason related to the values revealed by Allah, both in the book and the hadiths of the Prophet Muhammad, and kauniyyah sciences that is, the sciences developed by human reason because of their interactions with nature. The consequences of the dichotomy, as mentioned as the terms of the dichotomy, have implications for the alienation of the religious sciences to modernity and keep the progress of science away from spiritual values.

2. In the perspective of Islamic education, science is an in-depth knowledge of the results of earnest efforts (ijtihād) from Muslim scientists ('ulamā' / mujtahīd) on practical and ukhrāwī issues by originating from the revelations of Allah Almighty so that science grows and develops hand in hand with religion. In the history of Islamic civilization, scholars live in harmony with scientists, many scientists are found in Islam as well as scholars. For example, Ibn Rusyd, aside from being an Islamic jurist author of the book Bidāyah al-Mujtahīd, is also a medical expert composing the paper al-Kullīyāt fĩ al-Thibb. Along with the times, the progress of science, and for practical purposes, a number of scholars try to classify science, including Al-Ghazali, divided the knowledge into two parts; fardlu 'ain and fardlu kifāyah, syarī'ah and ghair syarī'ah; Ibn Khaldun split knowledge into two groups, namely; naqlìyah sciences originating from shari'a and 'aqliyah sciences/ philosophies originating from thought; Al-Farābī groups knowledge into five parts, namely; linguistics, logic, propaedeutic science, physics and mathematics, social science, law, and kalam. Based on the classification of these sciences confirms that the scope of knowledge in Islam is comprehensive, covering worldly affairs and ukhrāwi. So in Islamic education, the development of expertise in the framework of monotheism as a form of devotion to Allah Almighty and for the welfare of humanity.

\section{REFERENCES}

Ashraf, S. (1993). Horison Baru Pendidikan Islam. Pustaka Firdaus..

Al-Munjid (1986). fi al-Lūghah wa al-A'lām. Beirut : Dār al-Masyriq.

Al-Nawāwī, A. Z. (2001). Riyād al- Shālihīn. Kairo: al-Maktabah al-Salafīyah.

Azizy, A. (2003). Pengembangan Ilmu-Ilmu Keislaman. Jakarta: Direktorat Perguruan Tinggi Agama Islam Departemen Agama RI.

Azra, A. (1999). Pendidikan Islam; Tradisi dan Modernisasi Menuju Millenium Baru. Jakarta: Logos.

Echols, J. d. (1992). Kamus Inggris-Indonesia. Jakarta: Gramedia Pustaka Utama.

Fadjar, A. M. (1999). Reorientasi Pendidikan Islam. Jakarta: Yayasan Pendidikan Islam Fajar Dunia.

Ghazali, A. (1975). Ihyā' 'Ulūm al-Dīn. Dār al-Fikr.

Ilham, D. (2020). Persoalan-Persoalan Pendidikan dalam Kajian Filsafat Pendidikan Islam. Didaktika: Jurnal Kependidikan, 9(2), 179-188. Retrieved from https://jurnaldidaktika.org/contents/ article/view/22

Kebudayaan, D. P. (2002). Kamus Besar Bahasa Indonesia, Edisi III, Cet. II. Jakarta: Balai Pustaka.

Kertanegara, M. (2002). Menembus Batas Panorama Filsafat Islam. Bandung: Mizan.

Madjid, N. (1984). Khazanah Intelektual Islam. Jakarta: Bulan Bintang.

Madjid, N. (1992). Islam Doktrin dan Peradaban; Sebuah Telaah Kritis tentang Masalah Keimanan, Kemanusiaan, dan Kemodernan. Jakarta: Paramadina.

Muhaimin. (2004). Wacana Pengembangan Pendidikan Islam. Surabaya: Pusat Studi Agama, Politik, dan Masyarakat (PSAMP) bekerja sama dengan Pustaka Pelajar. 
Munawwir, A. W. (1984). Al-Munawwir; Kamus Arab-Indonesia. Yogyakarta: Unit Pengadaan Buku-Buku Ilmiah Keagamaan Pondok Pesantren al-Munawwir.

Muryi, A. M. (1986). al-Tarbiyah al-islamiyah: Ushuluha Wa Tathawwuruha. Kairo: Maktabah Dar al'Alam.

Nasution, H. (1996). Islam Rasional. Bandung: Mizan.

Nizar, S. (2008). Sejarah Pendidikan Islam. Jakarta: Kencana.

Rahardjo, M. D. (1990). Ensiklopedi al-Qur'ān: Ilmu, dalam Ulumul Qur'ān, Vol.1, No. 4. 